\title{
The Relationship Between Myocardial Bridge and Electrocardiographic Tp-e Interval, Tp-e/QT and Tp-e/ QTc Ratio
}

\section{Elektrokardiyografik Tp-e Intervali, Tp-e/QT ve Tp-e/QTc Oranı ile Miyokardiyal Bridge Arasındaki ilişki}

\author{
Erkan Yıldırım, Emrah İpek, Kamuran Kalkan, Mustafa Öztürk, Mahir Cengiz* , Hikmet Hamur** \\ Erzurum Region Training and Research Hospital, Clinic of Cardiology, Erzurum, Turkey \\ * Istanbul University Cerrahpaşa Faculty of Medicine, Department of Internal Diseases, Istanbul, Turkey \\ **Erzincan University Faculty of Medicine, Department of Cardiology, Erzincan, Turkey
}

Abstract

\begin{abstract}
Aim: Myocardial bridge (MB) is generally known as an asymptomatic and benign anomaly, however, it can cause serious clinical conditions such as exercise-induced ventricular tachycardia and sudden death. Tp-e interval is the distance between the peak and the end of the $\mathrm{T}$ wave in electrocardiography. Tp-e/QT and Tp-e/QTc ratios are used as electrocardiographic indicators of ventricular arrhythmias. We have studied the effect of coronary angiographic features (the degree of stenosis and length of $\mathrm{MB}$ ) of $\mathrm{MB}$ on myocardial repolarization parameters.
\end{abstract}

Methods: The study group consisted of 53 patients with isolated MB and 58 patients with normal coronary arteries.

Results: The QT interval and QTc were similar between the groups, however, Tp-e interval $(92.72 \pm 14.72$ and $79.59 \pm 12.12$, respectively; $p<0.001)$ and Tp-e/QT $(0.24 \pm 0.041$ and $0.21 \pm 0.025$, respectively; $p<0.001)$ and Tp-e/QTc $(0.22 \pm 0.037$ and $0.19 \pm 0.025$, respectively; $p<0.001)$ ratios were found to be significantly increased in $M B$ group compared to the control group. In the comparison of the $M B$ patients with critical and those with noncritical stenosis, Tp-e interval $(100.69 \pm 10.79,80.57 \pm 11.25$, respectively; $p<0.001)$ and Tp-e/QT $(0.266 \pm 0.033,0.219 \pm 0.037$, respectively; $p<0.001)$ and Tp-e/QTc $(0.244 \pm 0.029,0.196 \pm 0.027$, respectively; $p<0.001)$ ratios were higher in the MB with critical stenosis group.

Conclusion: Our results indicate that these parameters can be practical ECG markers of ventricular arrhythmias in patients with MB.

Keywords: Myocardial bridge, critical stenosis, Tp-e interval
Giriş: Miyokardial bridge (MB) genellikle asemptomatiktir ve iyi huylu olarak bilinir ancak egzersizin indüklediği ventriküler taşikardi, ani ölüm gibi ciddi klinik durumlara neden olabilir. Tp-e intervali elektrokardiyografide T dalgasının tepesi ile sonu arasındaki mesafedir. Tp-e/QT ve Tp-e/QTc oranları ventriküler aritmilerin elektrokardiyografik göstergesi olarak kullanılır. Biz MB'nin koroner anjiyografik özelliklerinin (MB'nin darlık derecesi ve uzunluğu) miyokardiyal repolarizasyon parametreleri üzerindeki etkisini araştırdık.

Yöntemler: Bu çalışma izole MB'li 53 ve normal koroner artere sahip 58 hastadan oluşmaktadır.

Bulgular: QT intervali ve QTc gruplar arasında benzerdi, Tp-e intervali $(92,72 \pm 14,72$ ve $79,59 \pm 12 ; 12, p<0,001)$, Tp-e/QT $(0,24 \pm 0,041$ ve $0,21 \pm 0,025 ; p<0,001)$ ve Tp-e/QTc $(0,22 \pm 0,037$ ve $0,19 \pm 0,025$; $p<0,001)$ kontrol grubu ile karşılaştırıldı̆ında MB grubunda belirgin olarak artmış bulundu. Kritik ve kritik olmayan darlığı bulunan $\mathrm{MB}$ hastaları karşılaştııılı̆̆ında, Tp-e intervali $(100,69 \pm 10,79 ; 80,57 \pm 11,25$; $p<0,001)$, Tp-e/QT $(0,266 \pm 0,033 ; 0.219 \pm 0,037 ; p<0,001)$ ve Tp-e/ QTc $(0,244 \pm 0,029 ; 0,196 \pm 0,027 ; p<0,001)$ kritik darlığı olan MB hastalarında daha yüksekti.

Sonuç: Sonuçlarımız MB hastalarında bu parametrelerin ventriküler aritmilerin pratik elektrokardiyografi belirteçleri olabileceğini göstermiştir.

Anahtar Sözcükler: Miyokardiyal bridge, kritik darlık, Tp-e interval
Address for Correspondence/Yazışma Adresi: Erkan Yıldırım

Erzurum Region Training and Research Hospital, Clinic of Cardiology, Erzurum, Turkey Phone: +90 4422325555 E-mail: drerkan23@yahoo.com

Received/Geliş Tarihi: 06 May 2016 Accepted/Kabul Tarihi: 12 June 2016
${ }^{\circ}$ Copyright 2017 by The Medical Bulletin of Haseki Training and Research Hospital The Medical Bulletin of Haseki published by Galenos Yayınevi. ๑Telif Hakkı 2017 Haseki Eğitim ve Araştırma Hastanesi Haseki Tıp Bülteni, Galenos Yayınevi tarafından basıımıştır. 


\section{Introduction}

Myocardial bridge (MB) is an inborn coronary anomaly which is defined as an abnormal intramyocardial course of a segment of a major coronary artery (1). Although MB can be seen in any of the epicardial coronary arteries, it is mostly observed in the left anterior descending artery with an incidence of $67-98 \%(2,3)$. In autopsy series, angiographically detected $\mathrm{MB}$ was reported to have a prevalence between $0.5 \%$ and $16 \%$ The rate of angiographic bridging is $<5 \%$, attributable to thin bridges causing little compression. In subjects with angiographically normal coronary arteries, the use of provocation tests may enhance systolic myocardial compression and thereby reveal MBs in $\leq 40 \%$ of cases and the length was found to be between 4 to $80 \mathrm{~mm}$ (4). MB is generally known to be an asymptomatic and benign anomaly, however, it can cause serious clinical conditions, such as severe myocardial ischemia, acute myocardial infarction, syncope, exerciseinduced ventricular tachycardia and atrioventricular block, acute left ventricular failure, and sudden death $(5,6)$.

Myocardial repolarization is evaluated by QT interval (QT), corrected QT interval (QTC), QT dispersion (QTd) and transmular dispersion of repolarization (TDR). Tp-e interval is the distance between the peak and the end of the $T$ wave in electrocardiography (ECG) and it is assumed as an index for TDR (7). Tp-e/QT and Tp-e/QTc ratios are used as electrocardiographic indicators of ventricular arrhythmias (8). We studied the effect of coronary angiographic features (the degree of stenosis and length of $M B$ ) of $M B$ on myocardial repolarization parameters.

\section{Methods}

\section{Study Population}

A total of 165 consecutive patients, who were referred to our clinic for diagnostic coronary angiography (CAG) between January and November 2015, were prospectively enrolled in the study. The study group consisted of 53 patients with isolated $\mathrm{MB}$ and 58 patients with normal coronary arteries. Patients with coronary artery disease (CAD), left ventricular systolic dysfunction, pulmonary hypertension, chronic obstructive pulmonary disease, diabetes, valvular disease, cardiomyopathy, abnormal thyroid function test, electrolyte imbalance, renal failure, and abnormal ECG, as well as those who had a pacemaker and on antiarrhythmic drug therapy were excluded. Patients whose ECGs could not be analyzed clearly were also excluded.

\section{Coronary Angiography}

The femoral route was used in all patients. The images were recorded in digital angiography system (ACOM.PC; Siemens, Germany and Digital Radiography System, Toshiba
DSR, Japan) with a speed of 15 frame per second. The contrast agent lopromide (Ultravist 370, Bayer Pharma AG, Berlin, Germany) was used. The conventional CAG images were evaluated by three independent cardiologists. MB was defined as an abnormal intramyocardial course of a segment of a major coronary artery. The length and degree of stenosis (\%) of the bridged segment were calculated angiographically by quantitative coronary analysis. The patients were allocated into two groups according to the degree of stenosis including MB with critical $(70 \%$ or greater stenosis) and noncritical stenosis (stenosis less than $70 \%$ ) groups.

\section{Electrocardiography}

Twelve-lead ECG was performed in each patient in the supine position by a conventional ECG device (Nihon Kohden, Tokyo, Japan) with a speed and amplitude of 25 $\mathrm{mm} / \mathrm{s}$ and $10 \mathrm{~mm} / \mathrm{mV}$, respectively. The ECG measurements were evaluated by two independent cardiologists who were blinded to the clinical data of the patients. In order to minimize the measurement errors, an electronic caliper was utilized. The mean value of the measurements was taken in order to increase accuracy. Heart rate and rhythm were determined and Tp-e interval and Tp-e/QT and Tp-e/ QTc ratios were measured. QT interval was defined as the distance between the onset of QRS and the end of T wave where it intersects the isoelectric line. QTc was calculated by Bazett's formula (9). The Tp-e interval was defined as the distance between the peak and the end of the T wave (Figure 1) (10). The measurement of Tp-e interval was performed using precordial leads as previously defined (11). The intraobserver and interobserver coefficients of variation [the standard deviation (SD) of differences between two observations divided by the mean value and expressed as a percentage] were found to be $<5 \%$.

\section{Echocardiography}

Transthorasic echocardiography was performed in all patients in the left lateral decubitus position by a

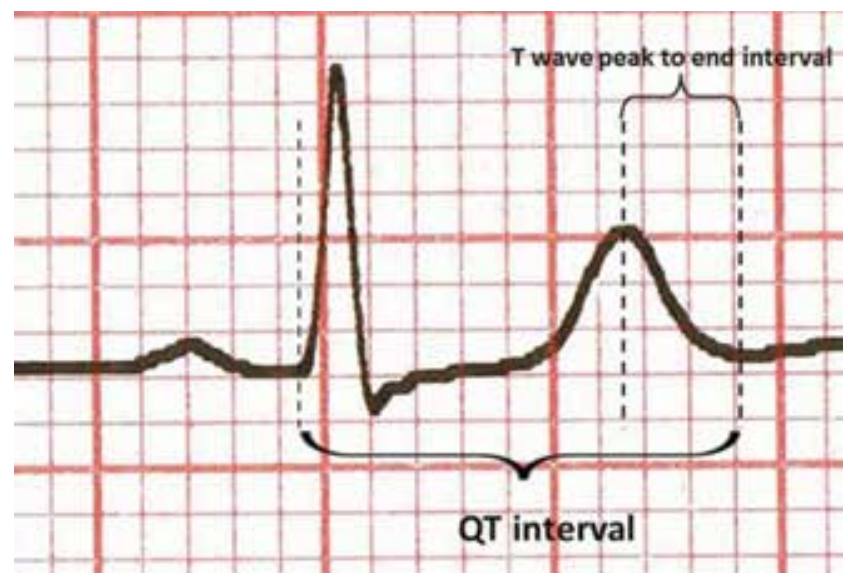

Figure 1. Demonstration of Tp-e and QT intervals 
Vivid 3 echocardiography device (GE Medical Systems, USA). The parasternal long and short axis, apical fourand two-chamber images were taken and evaluated according to the criteria of the American Society of Echocardiography (12).

\section{Statistics Analysis}

The normal distribution of data was tested by the 1-sample Kolmogorov-Smirnov test. Continuous variables are presented as mean \pm SD. Categorical variables are presented as counts. All statistical comparisons were performed using the two-sided Student's t-test. Categorical variables were compared using the chi-square test or Fisher's exact test for small samples. Pearson's correlation was used for numerical data. Spearman's correlation was used for nominal data. A $p$ value of less than 0.05 was considered statistically significant. Multivariate logistic regression model was performed to determine the effect of independent risk factors for prolonged Tp-e interval. Statistical analyses were performed using SPSS 22.0 software for Windows (SPSS Inc, Chicago, IL).

\section{Results}

A total of 165 patients were evaluated initially and after exclusion of 54 patients, 111 patients were included in the study. The number of patients with MB and controls was 53 and 58, respectively. The general characteristics of the study groups are shown in Table 1. 49 of the participants were female $(44 \%)$ while 62 were male $(56 \%)$ and the average age of the participants was $54.66 \pm 9.53$ years in $M B$ group and $60 \pm 9.15$ years in the control group. Age and gender distribution did not differ between the groups. There were no significant differences between the groups in terms of baseline laboratory and clinical characteristics. The length of $M B$ was found to be $15.1 \pm 3.7 \mathrm{~mm}$ in the $M B$ patient group and the degree of diameter reduction in the bridged segments was found to be $69 \pm 15.4 \%$. In MB group, the number of patients with critical $(70 \%$ or greater stenosis) and non-critical stenosis (stenosis less than 70\%) was found to be $32(60.7 \%)$ and 21 (39.6\%), respectively. No significant differences were observed in terms of conventional echocardiographic measurements between the groups ( $p>0.05$ ) (Table 1). The QT interval and QTc were similar between the groups, however, Tp-e interval $(92.72 \pm 14.72$ and $79.59 \pm 12.12$, respectively; $p<0.001)$, Tp-e/QT $\quad(0.24 \pm 0.041$ and $0.21 \pm 0.025$, respectively; $p<0.001)$ and Tp-e/QTc $(0.22 \pm 0.037$ and $0.19 \pm 0.025$, respectively; $p<0.001$ ) ratio were found to be significantly increased in MB group compared to the control group (Table 1). In the comparison of the MB patients with critical and noncritical stenosis, Tp-e interval $(100.69 \pm 10.79$, $80.57 \pm 11.25$, respectively; $p<0.001)$ and Tp-e/QT $(0.266 \pm 0.033,0.219 \pm 0.037$, respectively; $p<0.001)$ and
Tp-e/QTc $\quad(0.244 \pm 0.029, \quad 0.196 \pm 0.027$, respectively; $p<0.001)$ ratios were higher in the MB with critical stenosis group compared to the ones with noncritical stenosis (Table 2). There was not any statistically significant difference between control and $M B$ with noncritical stenosis groups in terms of ECG parameters. Multivariate analysis demonstrated that the degree of diameter reduction (standardized b coefficient $=0.681 ; p<0.001$ ) is an independent predictor of a prolonged Tp-e interval in the multivariate stepwise logistic regression model (Table 3).

\section{Discussion}

Our study is important as it showed significantly increased Tp-e interval and Tp-e/QT and Tp-e/QTc ratios in $\mathrm{MB}$ patients with angiographically detected critical stenosis, although there was not any significant relationship between these parameters and bridge length. These findings can be an evidence of relationship between ventricular repolarization change and MB. These results can also contribute to the explanation of pathophysiologic mechanisms of ventricular arrhythmias and the increase in the prevalence of sudden cardiac death among patients with MB.

In some studies, it was shown that increased repolarization dispersion alone can lead to ventricular arrhythmias $(13,14)$. In a study by ilgenli et al. (15) the ventricular arrhythmias were reported to have a significant correlation with longer Tp-e intervals.

The duration of action potential (AP) is longer in midmyocardial $\mathrm{M}$ cells than in the other myocardial cells (16). The repolarization is completed first in epicardial cells. The end of epicardial AP indicates the peak of the $T$ wave and the end of the midmyocardial AP indicates the end of the $T$ wave. As a result, the Tp-e interval shows the transmural dispersion of repolarization (16). In previous studies, the relationship of increased Tp-e interval with Brugada syndrome, myocardial infarction treated by primary percutaneous coronary intervention $(\mathrm{PCl})$, long QT syndrome, hypertrophic cardiomyopathy (HCM) (1114), obstructive sleep apnea syndrome (17), mitral valve prolapsus (10), heavy smoking (15), and exercise in MB patients (18), was studied.

The characteristic angiographic finding of $M B$ is systolic stenosis (milking effect). On the other hand, the intracoronary ultrasound and Doppler studies have shown that coronary obstruction also involves the diastolic period. Additionally, these studies indicated that a decrease in systolic minimal lumen diameter (MLD) greater than 70\% and a decrease in mid to late diastolic MLD more than $35 \%$ indicate a significant obstruction in the bridged segment $(19,20)$. Exercise and emotional stress increase 
heart rate and contractility leading to increased oxygen demand. These conditions can trigger ischemia in patients with $\mathrm{MB}$.

The data about the relationship between $M B$ and atherosclerosis is scant. In contrast to the location of the $M B$, the proximal part of the bridged segment has been reported to be more prone to the atherosclerotic process (21). Two main reasons for atherosclerosis in the proximal part have been shown to be increased shear stress on the vessel wall and distribution of blood flow (22). Additionally, the vasoactive agents (endothelin-1, endothelial nitric oxide synthase, angiotensin-converting

\begin{tabular}{|c|c|c|c|}
\hline Variables & Control group $(n=58)$ & MB group $(n=53)$ & $p$ \\
\hline Age, years & $60 \pm 9.15$ & $54.66 \pm 9.53$ & 0.131 \\
\hline Gender, male \% & 56 & 54.7 & 0.825 \\
\hline White blood cell count, $10^{3} / \mathrm{mm}^{3}$ & $9.1 \pm 1.25$ & $9.1 \pm 1.3$ & 0.690 \\
\hline Hemoglobin, gr/L & $13.33 \pm 0.83$ & $13.36 \pm 0.82$ & 0.887 \\
\hline Hemotocrit & $38.9 \pm 2.35$ & $38.93 \pm 2.33$ & 0.993 \\
\hline Platelet count, $/ \mathrm{mm}^{3}$ & $220 \pm 84$ & $228 \pm 84.26$ & 0.553 \\
\hline Creatinine, $\mathrm{mg} / \mathrm{dL}$ & $0.69 \pm 0.17$ & $0.69 \pm 0.17$ & 0.848 \\
\hline Triglyceride, mg/dL & $156.88 \pm 22.75$ & $157.28 \pm 22.17$ & 0.948 \\
\hline Total cholesterol, mg/dL & $188.67 \pm 15.95$ & $188.62 \pm 15.75$ & 0.988 \\
\hline $\mathrm{HDL}, \mathrm{mg} / \mathrm{dL}$ & $40.52 \pm 2.77$ & $40.74 \pm 2.71$ & 0.558 \\
\hline $\mathrm{LDL}, \mathrm{mg} / \mathrm{dL}$ & $111.33 \pm 11.83$ & $111.92 \pm 13.06$ & 0.896 \\
\hline Glucose, $\mathrm{mg} / \mathrm{dL}$ & $86.86 \pm 7.29$ & $87.25 \pm 7.17$ & 0.687 \\
\hline $\mathrm{Na}, \mathrm{mmol} / \mathrm{L}$ & $139.34 \pm 3.27$ & $139.91 \pm 3.2$ & 0.410 \\
\hline $\mathrm{K}, \mathrm{mmol} / \mathrm{L}$ & $4.5 \pm 0.35$ & $4.62 \pm 0.38$ & 0.564 \\
\hline $\mathrm{Ca}, \mathrm{mg} / \mathrm{dL}$ & $9.27 \pm 0.45$ & $9.19 \pm 0.44$ & 0.328 \\
\hline Systolic BP, mmHg & $121.12 \pm 10.84$ & $124.62 \pm 14.23$ & 0.248 \\
\hline Diastolic BP, mmHg & $78.19 \pm 4.83$ & $79.43 \pm 5.34$ & 0.282 \\
\hline Heart rate, beat/min & $78.98 \pm 12.55$ & $79.23 \pm 12.43$ & 0.903 \\
\hline LVEDD, $\mathrm{mm}$ & $48.21 \pm 2.19$ & $48.23 \pm 2.22$ & 0.905 \\
\hline LVESD, mm & $31.88 \pm 4.11$ & $31.92 \pm 4.12$ & 0.961 \\
\hline LVEF, \% & $61.02 \pm 2.98$ & $60.96 \pm 3.006$ & 0.905 \\
\hline LA, mm & $33.78 \pm 1.82$ & $34.06 \pm 1.86$ & 0.455 \\
\hline IVS thickness, mm & $9.98 \pm 0.63$ & $9.96 \pm 0.64$ & 0.864 \\
\hline PW thickness, $\mathrm{mm}$ & $9.98 \pm 0.63$ & $9.96 \pm 0.64$ & 0.864 \\
\hline Tp-e, msec & $79.59 \pm 12.12$ & $92.72 \pm 14.72$ & $<0.001$ \\
\hline $\mathrm{QT}$, msec & $368.62 \pm 21.39$ & $375.85 \pm 25.90$ & 0.193 \\
\hline QTc, msec & $409.45 \pm 21.06$ & $411.77 \pm 13.58$ & 0.095 \\
\hline Tp-e/QT ratio & $0.21 \pm 0.025$ & $0.24 \pm 0.041$ & $<0.001$ \\
\hline Tp-e/QTc ratio & $0.19 \pm 0.025$ & $0.22 \pm 0.037$ & $<0.001$ \\
\hline $\begin{array}{l}\text { Site of MB } \\
\text { LAD, n (\%) } \\
\text { LCX, n (\%) } \\
\text { RCA, n (\%) }\end{array}$ & & $\begin{array}{l}49(92.5) \\
2(3.8) \\
2(3.8)\end{array}$ & \\
\hline $\begin{array}{l}\text { Degree of stenosis, } \\
<70, \mathrm{n}(\%) \\
\geq 70, \mathrm{n}(\%)\end{array}$ & & $\begin{array}{l}21(39.6) \\
32(60.7)\end{array}$ & \\
\hline $\begin{array}{l}\text { Length of } \mathrm{MB}(\mathrm{mm}) \\
\text { degree of diameter reduction (\%) }\end{array}$ & & $\begin{array}{l}15.1 \pm 3.7 \\
69 \pm 15.4\end{array}$ & \\
\hline
\end{tabular}


enzyme) were detected to be in higher concentrations in the proximal part than in the bridged segment (23).

Another probable mechanism of ischemia in patients with $\mathrm{MB}$ is coronary vasospasm (24). The coronary vasospasm has been shown to be present in the proximal part of the bridged segment (25). This may be due to vasoactive agents released from this part. The recent histopathologic studies indicated that myocardial fibrosis and interstitial edema can occur in the area of MB (26). Similarly, in a report by Hostiuc et al. (27), significant myocardial fibrosis and interstitial edema were demonstrated in the bridged segment in patients who had sudden cardiac death. Death in these patients was emphasized to be related to increased electrical instability due to myocardial fibrosis.

The relationship of Tp-e interval and Tp-e/QT and Tp-e/QTc ratios with myocardial ischemia was studied previously by some researchers. Xiao et al. (28) reported a significant decrease in Tp-e and QTc intervals, and Tp-e/ QT ratio in patients with ST segment elevation myocardial infarction (STEMI) after successful thrombolytic therapy. In a study by Tatlisu et al. (29), Tp-e interval was shown to be a predictor of target vessel revascularization and death in patients with STEMI.

The shortening of Tp-e interval was demonstrated in STEMI patients with successful reperfusion who were treated by primary $\mathrm{PCl}$ (30). Aksan et al. (18) showed a significant increase in Tp-e interval and Tp-e/QT ratio after exercise in patients with MB. The findings of these two studies indicated that the percentage of MB stenosis and length of the bridged segment are the predictors of lengthening of Tp-e interval. In contrast, in our study, we did not see any significant relationship between the length of the bridged segment and the repolarization parameters. Here, we can speculate that the length of the bridged segment may not have a more important role in producing ischemia than the degree of stenosis.

\section{Study Limitations}

The number of study population is small. More accurate results can be achieved in a larger study group. Additionally, the relationship of Tp-e interval with ventricular arrhythmia incidence could not be evaluated. As a result, the prognostic role of increase in Tp-e interval and Tp-e/QT and Tp-e/QTc ratios in this patient group remained unclear.

\section{Conclusion}

In our study, we tried to figure out the relationship between angiographically detected MB and echocardiographic repolarization parameters. The Tp-e interval and Tp-e/QT and Tp-e/QTc ratios were found to be significantly increased in MB patients with $70 \%$ or greater stenosis. As a result, the presence of critical stenosis in the bridged segment should alert the physician about the deadly complications such as ventricular arrhythmias and sudden cardiac death.

Additionally, our results may indicate that these parameters can possibly be practical ECG markers of morbidity and mortality in patients with MB.

\section{Ethics}

Ethics Committee Approval: The study has been approved by Erzurum Region Training and Research Hospital Ethics Committee. Informed Consent: written informed consent was obtained from each participant.

Peer-review: Externally peer-reviwed.

\section{Authorship Contributions}

Surgical and Medical Practices: Erkan Yıldırım, Kamuran Kalkan. Concept: Erkan Yıldırım, Emrah İpek. Design: Erkan Yıldırım, Emrah Ipek. Data Collection or Processing:

\begin{tabular}{|l|l|l|l|}
\hline \multicolumn{2}{|l|}{ Table 2. Electrocardiographic repolarization parameters in non-critical and critical stenosis groups } \\
\hline Variables & Non-critical stonosis $\mathbf{( n = 2 1 )}$ & Critical stenosis (n=32) & $\mathbf{p}$ \\
\hline Tp-e, msec & $80.57 \pm 11.25$ & $100.69 \pm 10.79$ & $<\mathbf{0 . 0 0 1}$ \\
\hline QT, msec & $370.48 \pm 25.78$ & $379.38 \pm 25.77$ & 0.225 \\
\hline QTc, msec & $410.19 \pm 10.46$ & $412.81 \pm 15.37$ & 0.497 \\
\hline Tp-e /QT ratio & $0.219 \pm 0.037$ & $0.266 \pm 0.033$ & $<\mathbf{0 . 0 0 1}$ \\
\hline Tp-e /QTcratio & $0.196 \pm 0.027$ & $0.244 \pm 0.029$ & $<\mathbf{0 . 0 0 1}$ \\
\hline msec: millisecond, QT: QT interval, QTc: Corrected QT, Tp-e: T wave peak to end interval & & \\
\hline
\end{tabular}

\begin{tabular}{|l|l|l|l|l|}
\hline \multicolumn{4}{|l|}{ Table 3. Multivariate logistic regression analysis to demonstrate independent predictors of prolonged Tp-e interval } \\
\hline Variables & Coefficient & SE & OR (95\% CI) & p \\
\hline Age, years & -0.071 & 0.172 & $-0.110(-0.457-0.236)$ & 0.526 \\
\hline Degree of narrowing & 0.681 & 0.122 & $0.648(0.403-0.894)$ & $<\mathbf{0 . 0 0 1}$ \\
\hline Bridging segment characteristics, length of MB (mm) & -0.139 & 0.503 & $-0.541(-1.551-0.469)$ & 0.287 \\
\hline MB: Myocardial bridge, OR: Odds ratio, SE: Standart error, Cl: Confident interval
\end{tabular}


Erkan Yıldırım, Emrah İpek, Kamuran Kalkan. Analysis or Interpretation: Erkan Yıldırım, Mustafa Öztürk, Hikmet Hamur. Literature Search: Mahir Cengiz, Erkan Yıldırım. Writing: Erkan Yıldırım, Emrah İpek.

Conflict of Interest: No conflict of interest was declared by the authors.

Financial Disclosure: The authors declared that this study received no financial support.

\section{References}

1. Angelini $P$, Trivellato $M$, Donis J, Leachman RD. Myocardial bridges: a review. Prog Cardiovasc Dis 1983;26:75-88.

2. Loukas $M$, Curry $B$, Bowers $M$, et al. The relationship of myocardial bridges to coronary artery dominance in the adult human heart. J Anat 2006;209:43-50.

3. Qian JY, Zhang F, Dong $M$, et al. Prevalence and characteristics of myocardial bridging in coronary angiogram-data from consecutive 5525 patients. Chin Med J(Engl) 2009;122:632-5.

4. Möhlenkamp S, Hort W, Ge J, Erbel R. Update on myocardial bridging. Circulation 2002;106:2616-22.

5. Morales AR, Romanelli R, Boucek RJ. The mural left anterior descending coronary artery, strenuous exercise and sudden death. Circulation 1980;62:230-7.

6. Bestetti RB, Costa RS, Zucolotto S, Oliveira JS. Fatal outcome associated with autopsy proven myocardial bridging of the left anterior descending coronary artery. Eur Heart J 1989; 10:573-6.

7. Kors JA, Ritsema van Eck HJ, van Herpen G. The meaning of the Tp-Te interval and its diagnostic value. J Electrocardiol 2008;41:575-80.

8. Gupta P, Patel C, Patel H, et al. T(p-e)/QT ratio as an index of arrhythmogenesis. J Electrocardiol 2008;41:567-74.

9. Day CP, McComb JM, Campbell RW. QT dispersion: an indication of arrhythmia risk in patients with long QT intervals. Br Heart J 1990;63:342-4.

10. Yontar OC, Karaagac K, Tenekecioglu E, Tutuncu A, Demir M, Melek M. Assessment of ventricular repolarization inhomogeneity in patients with mitral valve prolapse: value of T wave peak to end interval. Int J Clin Exp Med 2014;7:2173-8.

11. Castro Hevia J, Antzelevitch $C$, Tornés Bárzaga F, et al. TpeakTend and Tpeak-Tend dispersion as risk factors for ventricular tachycardia/ventricular fibrillation in patients with the Brugada syndrome. J Am Coll Cardiol 2006;47:1828-34.

12. Zhao X, Xie Z, Chu Y, et al. Association between Tp-e/QT ratio and prognosis in patients undergoing primary percutaneous coronary intervention for ST-segment elevation myocardial infarction. Clin Cardiol 2012;35:559-64.

13. Topilski I, Rogowski O, Rosso R, et al. The morphology of the QT interval predicts torsade de pointes during acquired bradyarrhythmias. J Am Coll Cardiol 2007;49:320-8.

14. Shimizu $M$, Ino $H$, Okeie $K$, et al. T-peak to T-end interval may be beter predictor of high-risk patients with hypertrophic cardiomyopathy associated with a cardiac troponin I mutation than QT dispersion. Clin cardiol 2002;25:335-9.

15. IIlgenli TF, Tokatlı A, Akpınar O, Kılıçaslan F. The effects of cigarette smoking on the Tp-e interval, Tp-e/QT ratio and Tp-e/QTc ratio. Adv Cli Exp Med 2015;24:973-8.
16. Yan GX, Antzelevitch C. Cellular basis for the normal T wave and the electrocardiographic manifestations of the long-QT syndrome. Circulation 1998;98:1928-36.

17. Kilicaslan F, Tokatli A, Ozdag F, et al. Tp-e interval, Tp-e/QT ratio, and Tp-e/QTc ratio are prolonged in patients with moderate and severe obstructive sleep apnea. Pacing Clin Electrophysiol 2012;35:966-72.

18. Aksan G, Nar G, Inci S, et al. Exercise-induced repolarization changes in patients with isolated myocardial bridging. Med Sci Monit 2015;21:2116-24.

19. Schwarz ER, Klues HG, vom Dahl J, Klein I, Krebs W, Hanrath P. Functional characteristics of myocardial bridging. A combined angiographic and intracoronary doppler flow study. Eur Heart J 1997; 18:434-42.

20. Bourassa MG, Butnaru A, Lesperance J, Tardif JC. Symptomatic myocardial bridges: overview of ischemic mechanisms and current diagnostic and treatment strategies. J Am Coll Cardiol 2003;41:351-9.

21. Ishii T, Asuwa N, Masuda S, Ishikawa Y. The effects of a myocardial bridge on coronary atherosclerosis and ischemia. J Pathol 1998;185:4-9.

22. Ge J, Eebel R, Görge G, Haude M, Meyer J. High wall shear stres proximal to myocardial bridging and atherosclerosis. Intracoronary ultrasound and pressure measurements. $\mathrm{Br}$ Heart 1995;73:462-5.

23. Masuda T, Ishikawa $Y$, Akasaka $Y$, Itoh $K$, Kiguchi $H$, Ishii T. The effect of myocardial bridging of the coronary artery on vasoactive agents and atherosclerosis localization. J Pathol 2001;193:408-14.

24. Maseri A, Beltrame JF, Shimokawa H. Role of coronary vasoconstriction in ischemic heart disease an search for novel therapeutic targets. Circ J 2009;73:394-403.

25. Ciampricotti R, el Gamal M. Vasospastic coronary occlusion associated with a myocardial bridge. Catheter Cardiovasc Diagn 1988;14:118-20.

26. Brodsky SV, Roh L, Ashar K, Braun A, Ramaswamy G. Myocardial bridging of coronary arteries: a risk factor for myocardial fibrosis? Int J Cardiol 2008;124:391-2.

27. Hostiuc S, Curca GC, Dermangiu D, Dermengiu S, Hostiuc M, Rusu MC. Morphological changes associated with hemodynamically significant myocardial bridges in sudden cardiac death. Thorac Cardiovasc Surg 2011;59:393-8.

28. Xiao WT, Wang XP, Gao CY, et al. Predictive value of corrected QT interval, corrected Tp-e interval and Tp-e/QT ratio on malignant arrhythmia events in acute ST-segment elevation myocardial infarction patients undergoing thrombolysis. Zhonghua Xin Xue Guan Bing Za Zhi 2012;40:473-6.

29. Tatlisu MA, Özcan KS, Güngör $B$, et al. Can the T-peak to T-end interval be a predictor of mortality in patients with ST-elevation myocardial infarction? Coron Artery Dis 2014;25:399-404.

30. Eslami V, Safi M, Taherkhani M, Adibi A, Movahed MR. Evaluation of QT, QT dispersion, and T-wave peak to end time changes after primary percutaneous coronary intervention in patients presenting with acute ST-elevation myocardial infarction. J Invasive Cardiol 2013;25:232-4. 